\title{
PENGARUH VOLUNTARY \\ DISCLOSURE TERHADAP EARNINGS RESPONSE COEFFICIENT
}

\author{
Teguh Gunawan Setyabudi \\ Sekolah Tinggi Ilmu Ekonomi Indonesia Surabaya (STIESIA) \\ Jl. Menur Pumpungan No.30, Surabaya, Jawa Timur, Indonesia \\ teguhgunawan@stiesia.ac.id
}

\section{9}

diterima 25 November 2017, direview 4 Desember 2017 , direvisi 17 Desember 2017 , diterima 16 Januari 2018.

Artikel ini tersedia di website: http://ejournal.umm.ac.id/index.php/jrak

Doi: $10.22219 /$ jrak.v8i1.27

\begin{abstract}
This study aims to examine and obtain empirical evidence on the effects of voluntary disclosure of earnings response coefficient. Research conducted at the manufacturing companies listed in Indonesia Stock Exchange. The results showed that the voluntary disclosure significant effect on earnings response coefficient. From the results of the regression analysis, it can be said that the greater voluntary disclosure, the lower the market response on earnings announcements. It is possible that the information voluntarily disclosed by the company are not sufficiently represent the expected future profits of investors, so that the shareholders would prefer to use the information in real income in the financial statements alone. Shareholders are not quite sure use voluntary information in making investment decisions that are not directly responding on the market. Variable quality auditor shown to have a significant effect on earnings response coefficient. Meanwhile, the variable leverage proven no effect on earnings response coefficient.
\end{abstract}

Keywords: earnings response coefficient, leverage, quality auditor, voluntary disclosure

\section{PENDAHULUAN}

Perusahaan saat ini menghadapi kompetisi yang semakin hari semakin tajam yang mengakibatkan persaingan sehingga harus diantisipasi sebaik mungkin agar perusahaan tetap dapat mencapai tujuan perusahaan yakni going concern. Perusahaan dengan harapan hidup harus memperoleh laba optimal dan menambah nilai perusahaan. Pencapaian tujuan perusahaan harus didukung dengan pengambilan keputusan atas informasi-informasi penting perusahaan. Informasi yang menjadi perhatian utama bagi para investor adalah informasi laba karena laba memberikan gambaran mengenai kinerja perusahaan. Kandungan informasi laba tercermin dalam harga saham (Beaver et al.,1979). Penelitian Lev (1989) menggunakan earnings response coefficient sebagai alternatif untuk mengukur relevansi nilai informasi laba. ERC didefinisikan sebagai perkiraan perubahan harga saham yang terjadi akibat adanya pengumuman laba perusahaan yang masuk ke informasi pasar. Rendahnya nilai earnings response coefficient menunjukkan bahwa laba kurang informatif bagi investor untuk pengambilan keputusan. Scott (2000) menyatakan bahwa ERC mengukur besarnya abnormal return saham dalam merespons komponen laba yang dihasilkan perusahaan.

Informasi yang diungkapkan perusahaan meliputi pengungkapan wajib (mandatory disclosure) dan pengungkapan sukarela (voluntary disclosure). Pengungkapan wajib (mandatory disclosure) merupakan pengungkapan yang diwajibkan sesuai peraturan BAPEPAM-LK, sedangkan pengungkapan sukarela (voluntary disclosure) adalah pengungkapan melebihi dari apa yang seharusnya diwajibkan. Voluntary disclosure mengungkapkan informasi-informasi yang dapat menambah nilai perusahaan. Namun, ada beberapa alasan perusahaan tidak sepenuhnya mengungkapkan informasi atau ada keengganan dari manajemen, antara lain pengungkapan informasi dapat memberikan keuntungan bagi pesaing, biaya pengungkapan yang tinggi, serta informaisi bagi serikat pekerja dalam hal tawar menawar upah (Sudarmadji, 2007). Widiastuti (2006) dalam Sayekti dan

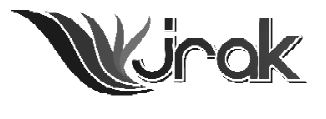

Jurnal Reviu Akuntansi dan Keuangan p-ISSN : 2615-2223 e-ISSN : 2088-0685 Vol. 8 No. 1, April 2018 Pp 69-78 


\section{Pengaruh \\ Masa \\ Perikatan \\ Audit...}

70

Wondabio (2007) menyatakan bahwa informativeness of earnings akan semakin besar ketika terdapat ketidakpastian mengenai prospek perusahaan di masa datang, semakin tinggi ketidakpastian prospek perusahaan di masa datang maka earnings response coefficient semakin tinggi . J ika perusahaan melakukan pengungkapan informasi dalam laporan tahunan dapat mengurangi adanya ketidakpastian sehingga pengungkapan informasi akan menurunkan earnings response coefficient. Perusahaan yang memiliki kor elasi return dan earnings response coefficient rendah mengindikasikan bahwa informasi laba hanya memberikan sedikit informasi tentang nilai perusahaan yang menunjukkan masih terdapat asimetri informasi yang tinggi (Lang dan Lundholm, 1993).

Earnings Response Coefficient (ERC) merupakan salah satu ukuran yang digunakan untuk mengukur kualitas laba. Laba yang berkualitas dapat ditunjukkan dari tingginya reaksi pasar ketika merespon informasi laba (J ang et al., 2007). Reaksi pasar tergantung dari kualitas laba yang dihasilkan perusahaan. ERC merupakan ukuran tentang besarnya return pasar sekuritas sebagai respon komponen laba tidak terduga yang dilaporkan perusahaan penerbit saham. Laba yang dipublikasikan dapat memberikan respon yang bervariasi, yang menunjukkan adanya reaksi pasar terhadap informasi laba. Reaksi yang diberikan tergantung dari kualitas laba yang di hasilkan ol eh perusahaan. Dengan kata Iain, Iaba yang dilaporkan memiliki kekuatan respon (power of response). Kekuatan reaksi pasar terhadap informasi laba yang tercermin dari tingginya ERC, menunjukkan laba yang berkualitas (J ang et al., 2007).

Teori sinyal menjelaskan manajer memiliki insentif secara sukarela melaporkan informasi kepada pasar (Astika, 2011:77). Laporan tahunan dan laporan keuangan merupakan salah satu informasi yang secara formal wajib dipublikasikan sebagai sarana pertanggungjawaban pihak manajemen terhadap pengel olaan sumber daya pemilik. Selain itu, laporan tahunan dan laporan keuangan merupakan jendela informasi yang memungkinkan bagi pihak-pihak diluar manajemen untuk mengetahui kondisi perusahaan. Namun sejauh mana informasi yang dapat diperol eh sangat tergantung pada tingkat pengungkapan (disclosure) dari laporan tersebut. Dengan adanya pengungkapan yang lebih luas, risiko yang dimiliki perusahaan pun dapat diketahui, dan hal tersebut mempengaruhi keputusan investasi dari investor. Pengungkapan dalam laporan keuangan akan membantu pengguna laporan keuangan untuk memahami isi dan angka dalam laporan keuangan. Kegagalan dalam memahami laporan keuangan mengakibatkan beberapa perusahaan mengalami kesalahan penilaian (misvalued), baik undervalued maupun overvalued. Sehingga muncul pertanyaan mengenai transparansi, pengungkapan informasi, dan peran akuntansi dalam menghasilkan informasi keuangan yang relevan dan dapat dipercaya, sehingga pemakai informasi akuntansi menerima sinyal tentang kondisi perusahaan yang sebenarnya.

Penelitian Murwaningsari (2007) menguji pengaruh pengungkapan sukarela dengan ERC, berpendapat bahwa luas pengungkapan sukarela berpengaruh positif terhadap ERC pada perusahaan manufaktur yang terdaftar di BEI tahun 20032006. Penelitian oleh Nugrahanti (2006) terhadap 47 perusahaan yang terdaftar di BEJ, kembali menunjukkan hasil yang sama, bahwa luas pengungkapan sukarela berpengaruh positif terhadap ERC. Penelitian Kartadjummena (2010) tentang pengaruh voluntary discl osure dan Corporate Social Responsibility (CSR) disclosureterhadap E RC. Hasil penelitian menunjukkan bahwa Voluntary discl osure of financial information tidak berpengaruh terhadap ERC. Penelitian Rahayu (2008) tentang pengaruh tingkat ketaatan pengungkapan wajib dan luas pengungkapan sukarela terhadap kualitas laba yang diukur dengan earnings response coefficient, menyimpulkan bahwa tingkat ketaatan pengungkapan wajib dan sukarela secara parsial ber pengar uh negatif terhadap kualitas laba yang diukur dengan ERC. Penelitian Sudarma (2015) tentang pengaruh voluntary disclosure terhadap Earnings Response Coefficient (ERC) menyimpulkan bahwa voluntary disclosure berpengaruh negatif pada ERC. Rata-rata pengungkapan sukarela yang relatif kecil menyebabkan pengungkapan sukarela yang dilakukan 
perusahaan kurang direspon atau memberikan sinyal negatif bagi pemakai laporan keuangan.

Berdasarkan hasil penelitian sebelumnya yang telah diuraikan diatas, menghasilkan simpulan yang tidak konsisten. Beberapa peneliti berpendapat bahwa vol untary disclosure berpengaruh terhadap ERC, sedangkan peneliti lain berpendapat bahwa vol untary discl osure ti dak berpengaruh terhadap E RC. Berdasarkan hal tersebut, peneliti termotivasi untuk menganal isis pengaruh voluntary disclosure terhadap earnings response coefficient pada perusahaan manufaktur terdaftar di Bursa Efek Indonesia. Voluntary disclosure dapat memberikan nilai tambah bagi calon investor dan berdampak pada respons laba. Pengukuran voluntary disclosure menggunakan daftar item pengungkapan, terdiri dari 33 item. Pengukuran E RC di per ol eh dari regresi antara proksi harga saham dan laba akuntansi. Proksi harga saham dengan cumulative abnormal return dan proksi laba akuntansi dengan unexpected earnings. Penelitian ini bertujuan untuk menguji dan memperol eh bukti empiris pengaruh voluntary disclosure terhadap earnings response coefficient pada perusahaan manufaktur di Indonesia.

\section{METODE PENELITIAN}

\section{Populasi dan Sampel Penelitian}

Populasi penelitian adalah perusahaan manufaktur terdaftar di Bursa Efek Indonesia pada tahun 2012 sampai dengan tahun 2015. Pemilihan sampel menggunakan purposive sampling berdasarkan pertimbangan (judgement sampling) dengan kriteria sebagai berikut: (1) Perusahaan manufaktur yang ter daftar di Bursa Efek Indonesia pada tahun 2012 sampai tahun 2015, (2) Perusahaan menerbitkan laporan keuangan maupun laporan tahunan secara lengkap dengan periode pelaporan tahunan yang berakhir pada tanggal 31 Desember selama periodetahun 2012 sampai tahun 2015, (3) Perusahaan memiliki data-data lengkap yang dibutuhkan dari tahun 2012 sampai tahun 2015.

\section{Klasifikasi Variabel dan Definisi Operasional Variabel Variabel Dependen}

Variabel dependennya adal ah earnings response coefficient. E RC didefinisikan sebagai efek setiap dolar unexpected earnings terhadap return saham, dan diukur dengan slope koefisien dalam regresi abnormal returns saham dan unexpected earning.

a. Cummulative abnormal return merupakan proksi harga saham yang menunjukkan besarnya respons pasar terhadap laba akuntansi yang dipublikasikan. Berikut tahapan menghitung besarnya cummulative abnormal return masingmasing perusahaan:

(1) Menghitung abnormal return:

$$
A R_{i t}=R_{i t}-R m_{i t}
$$

Keterangan:

$A R_{i t}=$ abnormal return perusahaan i pada hari $\mathrm{t}$.

$R_{i t} \quad=$ return sesungguhnya perusahaan i pada hari $\mathrm{t}$.

$R m_{i t}=$ return pasar perusahaan i pada hari t.

(2) Menghitung return sesungguhnya:

$$
R_{i t}=\frac{P_{i t}-P_{i t-1}}{P_{i t-1}}
$$


Pengaruh

Masa

Perikatan

Audit...

72

Keterangan:

$R_{i t} \quad=$ return sesungguhnya perusahaan i pada hari t.

$P_{i t}$. = harga saham penutupan perusahaan i pada hari $\mathrm{t}$.

$P_{i t-1}=$ harga saham penutupan perusahaan i pada hari sebelum $\mathrm{t}$.

(3) Menghitung return pasar:

$R m_{i t}=\frac{I H S G_{t}-I H S G_{t-1}}{I H S G_{t-1}}$

Keterangan:

$R m_{i t} \quad=$ return pasar pada hari $\mathrm{t}$.

$I H S G_{t} \quad=$ indeks harga saham gabungan pada hari t.

$I H S G_{t-1}=$ indeks harga saham gabungan pada hari sebelum t.

(4) Menghitung return sesungguhnya:

$R_{i t}=\frac{P_{i t}-P_{i t-1}}{P_{i t-1}}$

Keterangan:

$R_{i t} \quad=$ return sesungguhnya perusahaan i pada hari t.

$P_{i t} . \quad=$ harga saham penutupan perusahaan i pada hari $\mathrm{t}$.

$P_{i t-1} \quad=$ harga saham penutupan perusahaan i pada hari sebelum $\mathrm{t}$.

(5) Menghitung return sesungguhnya:

$R_{i t}=\frac{P_{i t}-P_{i t-1}}{P_{i t-1}}$

Keterangan:

$R_{i t} \quad=$ return sesungguhnya perusahaan i pada hari t.

$P_{i t} . \quad=$ harga saham penutupan perusahaan i pada hari $\mathrm{t}$.

$P_{i t-1} \quad=$ harga saham penutupan perusahaan i pada hari sebelum $\mathrm{t}$.

(6) Menghitung return pasar:

$R m_{i t}=\frac{I H S G_{t}-I H S G_{t-1}}{I H S G_{t-1}}$

Keterangan:

$R m_{i t} \quad=$ return pasar pada hari $\mathrm{t}$.

$I H S G_{t} \quad=$ indeks harga saham gabungan pada hari t.

$I H S G_{t-1}=$ indeks harga saham gabungan pada hari sebelum $\mathrm{t}$.

Dalam hal ini $\mathrm{CAR}_{\text {it }}$ merupakan CAR perusahaan i pada tahun $t$ dan $A R_{\text {it }}$ merupakan abnormal return perusahaan i pada hari t. CAR dihitung selama 5 hari sebelum laporan keuangan dipublikasikan dan 5 hari setelah laporan keuangan dipublikasikan.

$C A R_{i(-5+5)}=\sum_{t=-5}^{t=+5} A R_{i t}$

b. Unexpected earnings merupakan proksi laba akuntansi yang menunjukkan kinerja intern perusahaan selama periodetertentu. Unexpected earnings dapat dihitung dengan menggunakan rumus sebagai berikut: 


$$
U E_{i t}=\frac{\left(E P S_{i t}-E P S_{i t-1}\right)}{P_{i t-1}}
$$

Keterangan:

$U E_{i t} \quad=$ unexpected earnings perusahaan i pada tahun $\mathrm{t}$.

$E P S_{i t} \quad=$ earnings per share perusahaan i pada tahun $\mathrm{t}$.

$E P S_{i t-1}=$ earnings per share perusahaan i pada tahun sebelum $\mathrm{t}$.

$P_{i t-1} \quad=$ harga saham perusahaan i pada tahun sebelum $\mathrm{t}$.

C. Earnings Response Coefficient (ERC) akan dihitung dari slope á pada hubungan CAR dengan UE.

$$
\mathrm{CAR}_{\mathrm{it}}=\alpha_{0}+\alpha_{1} \mathrm{UE}_{\mathrm{it}}+\varepsilon
$$

Keterangan:

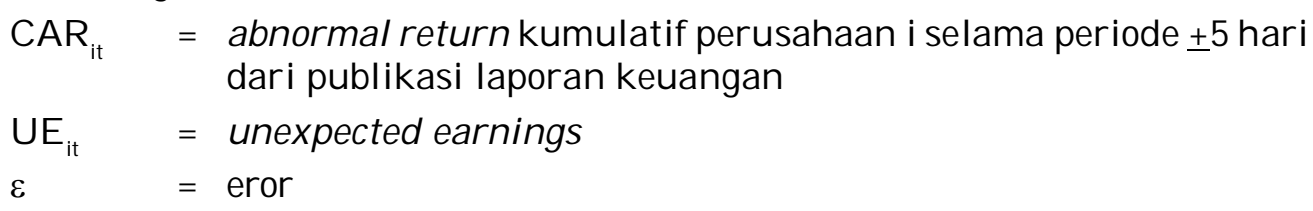

\section{Variabel Independen}

Variabel independen dalam penelitian ini adalah voluntary disclosure. Voluntary disclosure adalah pengungkapan tambahan diluar pengungkapan yang diwajibkan sesuai dengan keputusan No. KE P-431/BL/2012 tentang penyampaian laporan tahunan emiten atau perusahaan publik. Pengukuran voluntary disclosure dengan menggunakan indeks vol untary disclosure. Voluntary disd osure mengukur berapa banyak butir dalam laporan tahunan yang diungkap. Butir voluntary disclosure terdiri dari 33 item informasi . I ndeks voluntary discl osuremerupakan perbandingan antara jumlah item vol untary discl osure terhadap total indeks voluntary disclosure. Rumus yang digunakan sebagai berikut.

$$
\text { Indeks Voluntary Disclosure }=\frac{\text { Jumlah Item Voluntary Disclosure }}{\text { Total Indeks Voluntary Disclosure }}
$$

\section{Variabel Kontrol \\ Kualitas Auditor}

Kualitas auditor diwujudkan dalam proses audit atas laporan keuangan secara profesional yang dapat mendeteksi ditemukannya kecurangan atau salah saji yang material. Auditor bersikap independen dan hati-hati dalam audit untuk mempertahankan kredi bilitasnya. Auditor yang berskala besar lebih dapat dipercaya, dibuktikan dengan earning response coefficient untuk perusahaan yang diaudit oleh auditor big six lebih besar dibandingkan dengan klien auditor non big six karena investor beranggapan bahwa laporan yang berkualitas lebih akurat dan dapat mencerminkan nilai ekonomi sesungguhnya. Pengukuran variabel kualitas auditor berdasarkan pengukuran Siregar dan Utama (2005). Ukuran KAP digunakan sebagai proksi kualitas audit. KAP big four memiliki reputasi yang baik, memiliki sumber daya yang berkualitas dan lebih kompeten dalam mengidentifikasi kesalahan akuntansi yang terjadi. Dalam melakukan audit, KAP big four akan lebih berhati-hati dalam kegiatan audit karena berafiliasi dengan asing dan akan mengungkapkan informasi lebih terperinci. Pengukuran variabel menggunakan variabel dummy, skor 1 untuk auditor yang termasuk dalam big four dan skor 0 untuk auditor yang tidak termasuk dalam big four. 


\section{Pengaruh \\ Masa \\ Perikatan \\ Audit...}

74

\section{L everage}

Leverage adalah sumber pendanaan operasional dan pendanaan investasi yang berasal dari luar perusahaan. Semakin tinggi leverage perusahaan maka utang perusahaan semakin tinggi. Besarnya rasio utang mencerminkan kompleksitas dan risiko keuangan. Leverage digunakan untuk menggambarkan kemampuan perusahaan dalam menggunakan aktiva atau dana yang mempunyai beban tetap untuk memperbesar tingkat penghasilan bagi pemiliki per usahaan. Dengan memperbesar tingkat leverage maka tingkat ketidakpastian dari return yang akan diperol eh akan semakin tinggi pula. Semakin tinggi tingkat leverage akan semakin tinggi tingkat risiko yang dihadapi serta semakin besar tingkat return atau penghasilan yang di harapkan. Variabel leverage diukur menggunakan rumus sebagai berikut.

$$
\text { Leverage }=\frac{\text { Total Hutang }_{i t}}{\text { Total Aset }_{i t}}
$$

\section{Teknik Analisis Data}

Analisis data yang digunakan dalam penelitian ini menggunakan analisis regresi berganda untuk mengetahui ada atau tidaknya pengaruh voluntary disclosure terhadap earnings response coefficient. Analisis data dilakukan dengan menggunakan software SPSS.

\section{Uji Asumsi Klasik}

Uji asumsi klasik dilakukan terlebih dahulu sebelum melakukan analisis regresi agar data terbebas dari bias. Uji asumsi klasik yang dilakukan meliputi: uji normalitas, uji multikolinearitas, uji heteroskedastisitas, dan uji autokorelasi.

\section{Uji Kelayakan Model}

Uji kelayakan model dilakukan sebelum melakukan pengujian hipotesis dengan tujuan untuk melihat apakah model regresi telah layak dilakukan pengujian selanjutnya. Uji F dilakukan untuk menguji apakah model penelitian layak untuk digunakan (model fit). Uji F dilakukan dengan melihat nilai signifikansi, jika nilai signifikansi <0,05 maka model layak (model fit) untuk digunakan dalam pengujian selanjutnya.

\section{Uji Koefisien Determinasi $\left(R^{2}\right)$}

Koefisien determinasi $\left(\mathrm{R}^{2}\right)$ digunakan untuk mengukur kemampuan model untuk menjelaskan perubahan yang terjadi pada earnings response coefficient.

\section{Uji Hipotesis}

Uji hipotesis menggunakan model regresi linier berganda. Analisis regresi berganda dilakukan untuk mengetahui pengaruh voluntary disclosure terhadap earnings response coefficient. M odel regresi berganda sebagai berikut.

$$
E R C=\alpha+\beta_{1} V D+\beta_{2} A U D T+\beta_{3} L E V+\varepsilon
$$

Pengujian hipotesis dilakukan dengan mencari nilai signifikansi hitung. J ika nilai signifikansi $<0,05$ maka dapat dikatakan ada pengaruh antara variabel independen terhadap variabel dependen. 
Uji normalitas dilakukan dengan menggunakan uji normal plot. Hasil uji normalitas menunjukkan data menyebar di sekitar diagonal dan penyebarannya mengikuti arah garis diagonal. $\mathrm{Hal}$ ini menunjukkan bahwa model regresi memenuhi asumsi normalitas dan dikatakan layak digunakan untuk mengetahui variabel dependen. Uji multikolinearitas digunakan untuk melihat apakah terjadi hubungan antar variabel independen. Untuk mendeteksi multikolinearitas dilakukan dengan melihat besaran nilai tolerance atau besaran nilai Variance Inflation Factor (VIF). Hasil uji multikolinearitas menunjukkan bahwa nilai tolerance lebih besar 0,1 atau nilai VIF kurang dari 10, maka dapat disimpulkan bahwa dalam model regresi tidak terjadi gejala multikolinearitas.

Uji heteroskedastistas dilakukan dengan menggunakan metodescatter plot's yaitu dengan melihat ada tidaknya pola-pola tertentu. Hasil uji heteroskedastisitas terlihat tidak ada bentukan pola tertentu, serta titik-titik menyebar di atas dan di bawah angka nol (0) pada sumbu Y. Hal ini menunjukkan bahwa tidak terjadi heter oskedastisitas, sehingga model regresi dapat dikatakan layak digunakan. Uji autokorelasi dilakukan untuk mengetahui apakah model regresi terjadi gejala autokorelasi. Hasil uji autokorelasi sebesar 1,889 menunjukkan bahwa nilai DW telah memenuhi kriteria $(-2<\mathrm{DW}<+2)$. $\mathrm{H}$ al ini menunjukkan bahwa model regresi telah memenuhi asumsi tidak terjadi autokorelasi.

\section{Koefisien Determinasi $\left(\mathbf{R}^{2}\right)$}

Besarnya Adjusted $\mathrm{R}^{2}$ menunjukkan besarnya prosentase pengaruh semua variabel independen terhadap variabel dependen. Nilai Adjusted $\mathrm{R}^{2}$ pada model regresi 1 sebesar 0,047. Hal ini menunjukkan 4,7\% perubahan yang terjadi pada cummulative abnormal return $(\mathrm{Y})$ dipengaruhi ol eh variabel voluntary disclosure, kualitas auditor dan leverage sedangkan sisanya 95,3\% dipengaruhi ol eh faktor lainnya. Standar E rror of Estimates pada model regresi sebesar 0,60962. Semakin kecil nilai Standar Error of Estimates akan membuat model regresi semakin tepat digunakan.

\section{Uji Hipotesis}

Setelah melakukan uji asumsi klasik dan uji kelayakan model, dapat dinyatakan bahwa persamaan model regresi layak digunakan. Langkah sel anjutnya adalah melakukan pengujian model regresi penelitian. Hasil uji analisis regresi berganda disajikan pada tabel berikut:

\begin{tabular}{cccccccc}
\hline M odel & \multicolumn{2}{c}{$\begin{array}{c}\text { Unstandardized } \\
\text { Coefficients }\end{array}$} & $\begin{array}{c}\text { Standardized } \\
\text { Coefficients }\end{array}$ & t & & Sig. & \multicolumn{2}{c}{$\begin{array}{c}\text { Collinearity } \\
\text { Statistics }\end{array}$} \\
\cline { 2 - 4 } & B & Std. E rror & Beta & & & Tolerance & VIF \\
\hline (Constant) &, 816 &, 248 & & 3,287 &, 001 & & \\
VD & $-1,250$ &, 351 &,- 190 & $-3,358$ &, 000 &, 995 & 1,005 \\
1 AUDT & -138 &, 069 &,- 107 & $-1,994$ &, 047 &, 985 & 1,015 \\
LEV &, 075 &, 067 &, 060 & 1,116 &, 265 &, 988 & 1,012 \\
\hline
\end{tabular}

Tabel 1

Hasil Analisis Regresi Berganda

Berdasarkan Tabel 1, persamaan regresi berikut ini:

$\mathrm{ERC}=0,816-1,250 \mathrm{VD}-0,138$ AUDT $+0,075$ LEV

Dari persamaan tersebut di atas, dapat dijelaskan bahwa nilai konstanta sebesar 0,816, artinya apabila variabel voluntary disclosure, kualitas audit dan leverage sama dengan 0 maka earnings response coefficient sebesar 0,816. Nilai 
Pengaruh

Masa

Perikatan

Audit...

76

koefisien regresi variabel vol untary discl osure sebesar $-1,250$, artinya jika vol untary disclosure meningkat satu persen, maka besar dari earnings response coefficient akan menurun sebesar 1,250 dengan asumsi variabel lain konstan atau tidak mengalami perubahan. Nilai koefisien regresi variabel kualitas audit sebesar 0,138 , artinya jika kualitas audit meningkat satu persen, maka besar dari earnings response coefficient akan menurun sebesar 0,138 dengan asumsi variabel lain konstan atau tidak mengalami perubahan. Nilai koefisien regresi variabel leverage sebesar 0,075, artinya jika leverage meningkat satu persen, maka besar dari earnings response coefficient akan meningkat sebesar 0,075. Nilai signifikansi untuk variabel voluntary discl osure $(0,000)$ dan kualitas auditor $(0,047)$ signifikan pada level $5 \%$. Sedangkan, variabel leverage $(0,265)$ tidak signifikan pada level $5 \%$.

\section{Pengaruh Voluntary Disclosure Terhadap Earnings Response Coeffi- cient}

Dari hasil analisis regresi berganda terlihat bahwa hasil pengujian model sebelum dimasukkan variabel kontrol menunjukkan bahwa variabel voluntary disclosure berhubungan dengan earnings response coefficient dengan tingkat signifikansi 5\%. Diketahui nilai koefisien regresi variabel vol untary disclosure sebesar $-0,1250$ dengan nilai signifikansi sebesar 0,000. Dari hasil anal isis regresi berganda terlihat bahwa hasil pengujian menunjukkan bahwa variabel voluntary disclosure berhubungan dengan earnings response coefficient dengan tingkat signifikansi $5 \%$. Earnings response coefficient sebagai perkiraan perubahan harga saham yang terjadi akibat adanya pengumuman laba perusahaan yang masuk ke informasi pasar. Rendahnya earnings response coefficient menunjukkan bahwa laba kurang informatif bagi investor untuk pengambilan keputusan. Semakin tinggi voluntary disclosure maka earnings response coefficient semakin kecil karena investor dal am mer espons pengumuman laba tidak hanya bergantung pada voluntary disclosure saja, namun perkembangan makro Indonesia.

Hasil penelitian sejalan dengan Purwaningsih dan Pradipta (2012), yang menyatakan bahwa semakin besar luas pengungkapan tanggung jawab sosial dan lingkungan perusahaan maka E RC perusahaan akan semakin kecil. Investor dapat mempertimbangkan informasi tanggung jawab sosial dan lingkungan perusahaan sebagai bahan pertimbangan dalam keputusan berinvestasi selain informasi laba. Namun, hasil penelitian ini tidak sejalan dengan penelitian Paramita (2012), U ntari dan Budiasih (2014), dan Firman (2014) yang menyatakan bahwa vol untary disclosure berpengaruh positif terhadap earnings response coefficient. Perusahaan yang transparan dalam pengungkapan informasi perusahaannya akan banyak membantu investor dalam membuat keputusan, sehingga perusahaan dengan tingkat pengungkapan sukarela akan berbeda secara substansial dalam hal jumlah tambahan informasi yang diungkapkan ke pasar modal. Semakin banyak perusahaan melakukan pengungkapan sukarela, maka akan semakin tinggi respons pasar. Sedangkan, Kartadjumena (2010) menyatakan bahwa voluntary discl osure tidak berpengaruh terhadap earnings response coefficient. Karena investor tidak cukup yakin dengan informasi sukarela yang diungkapkan manajemen sehingga investor tidak menggunakan informasi tersebut sebagai dasar mengambil keputusan dan informasi sukarela yang diungkapkan perusahaan tidak cukup memberikan informasi tentang expected future earnings sehingga investor tetap akan menggunakan informasi laba dalam laporan tahunan.

\section{KE SIMPULAN}

Penelitian ini bertujuan untuk menguji pengaruh voluntary disclosure terhadap earnings response coefficient. Penelitian dilakukan pada perusahan manufaktur yang terdaftar di Bursa Efek Indonesia. Hasil penelitian menunjukkan 
bahwa voluntary disclosure berpengaruh signifikan terhadap earnings response coefficient. Hal ini dibuktikan dari hasil analisis regresi berganda. Dari hasil tersebut dapat dikatakan bahwa semakin besar pengungkapan informasi yang dilakukan ol eh perusahaan secara sukarela, maka semakin rendah respons pasar atas pengumuman laba semakin rendah. Hal ini mungkin saja terjadi karena informasi sukarela yang diungkapkan oleh perusahaan tidak cukup merepresentasi laba masa depan yang diharapkan investor, sehingga pemegang saham akan lebih suka menggunakan informasi laba riil dalam laporan keuangan saja. Selain itu, dimungkinkan para pemegang saham tidak cukup yakin menggunakan informasi sukarela dalam pengambilan keputusan investasi sehingga pemegang saham tidak langsung merespons di pasar dengan menggunakan informasi tersebut. Oleh karena itu, pengungkapan sukarela perusahaan kurang dapat digunakan untuk memprediksi koefisien respons laba.

Penelitian ini hanya dilakukan pada perusahaan manufaktur. Bagi penelitian selanjutnya, diharapkan dapat menambah variabel lain yang mempengaruhi earnings response coefficient, antara lain: variabel struktur modal, kesempatan bertumbuh, ukuran perusahaan, persistensi laba, ketepatan waktu pelaporan, konservatismelaba, dan lain sebagainya. Sel ain itu, dalam penelitian ini, pengukuran voluntary disclosure hanya menggunakan 33 item penilaian, sehingga bagi penelitian selanjutnya dapat menambah jumlah item untuk pengukurannya. Hasil penelitian ini diharapkan dapat menjadi masukan bagi para pelaku usaha, investor, lembaga pasar modal terkait, serta para penyusun standar akuntansi mengenai pengungkapan informasi secara sukarela dalam laporan tahunan perusahaan.

\section{DAFTAR PUSTAKA}

Astika, I.B. P. 2011. Teori Akuntansi: Konsep Dasar Akuntansi Keuangan. Buku Satu. Buku Ajar Pada Fakultas Ekonomi Universitas U dayana. Bali.

Beaver, W. H., R. Clarke, dan W. F. Wright. 1979. TheAssociation Between Unsystematic Security Returns and The Magnitude of Earning F orecast E rror.J ournal of Accounting Research. Vol. 17.

Firman, M. 2014. Analisis Faktor-F aktor yang Mempengaruhi E arnings Response Coefficient. J urnal IImiah Universitas Bakrie. Vol. 2. No. 2.

J ang, L., B. Sugiarto, dan D. Siagian. 2007. Faktor-faktor yang Mempengaruhi Kualitas Laba pada Perusahaan Manufaktur di BEJ . Akuntabilitas. Vol. 6 No. 2.

Kartadjumena, E . 2010. Pengaruh Voluntary Disclosure Of Financial Information dan CSR Disclosure Terhadap Earnings Response Coefficient. The $4^{\text {th }}$ PPM National Conference on Management Research.

Lang, M. dan R. J . Lundholm. 1993. Cross sectional determinants of analysist rating of corporate discl osure. J ournal of Accounting Research. Vol. 31.

Lev, B. 1989. On U sefulness of E arnings: Lesson and Directions F rom Two Decades of Empirical Research. J ournal of Accounting Research. Vol. 27.

Nugrahanti, Y. W. 2006. Hubungan Antara Luas Ungkapan Sukarela Dalam Laporan Tahunan Dengan Earnings Response Coefficient Dan Volume Perdagangan Pada Saat Pengumuman Laba. J urnal Ekonomi dan Bisnis. Vol. 8. No. 2.

Paramita, R.W. D. 2012. Pengaruh Leverage, Firm Size Dan Voluntary Disclousure Terhadap Earnings Response Coeffisient (ERC). J urnal WIGA. Vol. 2.

Purwaningsih, A. dan Pradipta. 2012. Pengaruh Luas Pengungkapan Tanggung J awab Sosial Dan Lingkungan Perusahaan Terhadap Earning Response Coefficient (ERC), Dengan Ukuran Perusahaan Dan Leverage Sebagai Variabel Kontrol . Simposium Nasional Akuntansi XV. Banjarmasin. 
Pengaruh

Masa

Perikatan

Audit...

78
Rahayu, S. I. 2008. Pengaruh Tingkat Ketaatan Pengungkapan Wajib Dan Luas Pengungkapan Sukarela Terhadap Kualitas Laba. Simposium Nasional Akuntansi VIII. Solo.

Sayekti, Y. dan L. S. Wondabio. 2007. Pengaruh Corporate Social Responsibility Discl osure Terhadap Earning ResponseCoefficient (Suatu Study E mpi ris Pada Perusahaan yang Terdaftar di Bursa Efek J akarta). Simposium Nasional Akuntansi X. Makassar.

Scott, W. R. 2000. Financial Accounting Theory. 2nd E dition. Pearson Prentice Hall. Ontario. Canada.

Siregar, S. V. N. P dan S. Utama. 2005. Pengaruh Struktur Kepemilikan, Ukuran Perusahaan, Dan Praktik Corporate Governanceterhadap Pengelolaan Laba. Simposium Nasional Akuntansi VIII. Solo.

Sudarma, I.P., 2015. Pengaruh Voluntary Disclosure Pada Earnings Response Coefficient. E-J urnal Akuntansi Universitas Udayana. Vol. 12. No. 2.

Sudarmadji, A. M. 2007. Pengaruh Ukuran Perusahaan, Profitabilitas, Leverage, Dan Tipe Perusahaan Terhadap Luas Vol untary Discl osure Laporan Keuangan Tahunan. Proceeding PESAT. Vol. 2.

Untari, M. D. A. dan I G. N. Budiasih. 2014. Pengaruh Konservatisme Laba Dan Voluntary Disclosure Terhadap Earnings Response Coefficient. E-J urnal Akuntansi Universitas Udayana. Vol. 7. No. 1. 